\title{
Remineralizer, vinasse, and cover crops on the biometric parameters and nutrition of common bean
}

\section{Remineralizador, vinhaça e plantas de cobertura em parâmetros biométricos e na nutrição de feijoeiro}

\section{Maicon Douglas Bispo de SOUZA ${ }^{1,2}$; Anastácia FONTANETTI Maria Leonor Ribeiro Cassimiro LOPES-ASSAD ${ }^{4}$}

${ }^{1}$ Parte da dissertação do primeiro autor.

${ }^{2}$ Mestre em Agroecologia e Desenvolvimento Rural, Universidade Federal de São Carlos, maicondbs@outlook.com.

${ }^{3}$ Doutora, Universidade Federal de São Carlos, Departamento de Desenvolvimento Rural, Centro de Ciências Agrárias, Araras, SP. Email.: anastacia@ufscar.br

${ }^{4}$ Autor para Correspondência, Doutora, Universidade Federal de São Carlos, Departamento de Recursos Naturais e Proteção Ambiental, Centro de Ciências Agrárias, Araras, SP. Email.: assad@ufscar.br

Recebido em: 25-01-2017; Aceito em: 24-08-2017

\begin{abstract}
The objective of this study was to evaluate the biometric parameters and leaf nutrient content of common bean (Phaseolus vulgaris L.) grown in succession to cover crops, as a function of the application of remineralizer doses (basalt powder) and vinasse. The experiment was conducted in a greenhouse in the experimental design of randomized blocks in a $4 \times 4 \times 2$ factorial scheme, with three replications. The first factor was remineralizer doses $(0,2$, 4 , and $8 \mathrm{t} \mathrm{ha}^{-1}$ basalt powder). The treatments with no cover crops (control) and with the cover crops crotalaria (Crotalaria juncea L.), millet (Pennisetum glaucum L.), and brachiaria (Urochloa cv. ruziziensis) constituted the second factor. The third factor corresponded to the presence or absence of vinasse $\left(200 \mathrm{~m}^{3} \mathrm{ha}^{-1}\right.$, and $0 \mathrm{~m}^{3} \mathrm{ha}^{-1}$, respectively). Plant height, shoot dry matter (SDM), leaf area index (LAl), Falker chlorophyll index (FCl), and leaf macronutrient content $(\mathrm{N}, \mathrm{P}, \mathrm{K}, \mathrm{Ca}, \mathrm{Mg}$, and $\mathrm{S})$ were evaluated. The association of cover crops, vinasse and remineralizer increased plant height and leaf contents of $\mathrm{K}, \mathrm{Ca}, \mathrm{Mg}$, and $\mathrm{S}$ at the evaluated stage, but vinasse had a positive effect only on S content. Remineralizer doses associated with cover crops provided satisfactory levels of leaf macronutrients for common bean.
\end{abstract}

Additional keywords: Crotalaria juncea; Pennisetum glaucum; Phaseolus vulgaris; rock powder; Urochloa cv. Ruziziensis.

\section{Resumo}

Objetivou-se com o trabalho avaliar parâmetros biométricos e teores de nutrientes foliares do feijoeiro (Phaseolus vulgaris L.) cultivado em sucessão a plantas de cobertura, em função da aplicação de doses de remineralizador (pó de basalto) e de vinhaça. O experimento foi conduzido em casa de vegetação, no delineamento experimental de blocos casualizados, em esquema fatorial $4 \times 4 \times 2$, com três repetições. $O$ primeiro fator foram doses de remineralizador (0; 2; 4 e $8 \mathrm{t} \mathrm{ha}^{-1}$ de pó de basalto). Os tratamentos sem plantas de cobertura (controle) e com as plantas de cobertura crotalária (Crotalaria juncea L.), milheto (Pennisetum glaucum L.) e braquiária (Urochloa cv. ruziziensis) representaram o segundo fator. $\mathrm{O}$ terceiro fator correspondeu à presença ou à ausência de vinhaça $\left(200 \mathrm{~m}^{3} \mathrm{ha}^{-1}\right.$ e $0 \mathrm{~m}^{3} \mathrm{ha}^{-1}$, respectivamente). Foram avaliados altura da planta, matéria seca da parte aérea (MSPA), índice de área foliar (IAF), índice de clorofila Falker (ICF) e teores de macronutrientes (N, P, K, Ca, Mg e S) foliares. A associação de plantas de cobertura, vinhaça e remineralizador proporcionou aumento da altura de plantas e dos teores foliares de $\mathrm{K}, \mathrm{Ca}, \mathrm{Mg}$ e $\mathrm{S}$, no estágio avaliado, mas a vinhaça causou efeito positivo apenas no teor de S. Doses de remineralizador associadas a plantas de cobertura proporcionaram níveis satisfatórios de macronutrientes foliares do feijoeiro.

Palavras-chave adicionais: Crotalaria juncea; Pennisetum glaucum; Phaseolus vulgaris; pó de rocha; Urochloa cv. Ruziziensis.

\section{Introduction}

Brazil is the second largest producer and the world's largest consumer of common bean (Phaseolus vulgaris L.), with a production of 2.57 million tons in the 2016 harvest (IBGE, 2017). The average national productivity in the $2015 / 2016$ harvest was $886 \mathrm{~kg} \mathrm{ha}^{-1}$, but in the Center-South region the average productivity reached $1,574 \mathrm{~kg} \mathrm{ha}^{-1}$, while in the North-Northeast region it was $276 \mathrm{~kg} \mathrm{ha}^{-1}$ (CONAB, 2017a). Such differences are due to the different cropping systems, which include the use of disease-resistant cultivars grown in intensive, irrigated, and highly technical farming systems, and crops with low technological use, 
and subsistence-based, without, or with reduced application of inputs.

A study by the National Supply Company (CONAB, 2017b) on bean production costs indicates that fertilizers are one of the most important components of operating costs and that the influence of the exchange rate on these costs is low. In Brazil, the application of fertilizers is concentrated on the production of maize and soybean (BNDES, 2006) and the variation in the prices of these inputs affects bean yield. Then it is necessary to adopt alternatives of soil fertility management. Thus, agroindustrial residues, which could generate environmental problems, such as mining residues and vinasse, have been used as soil and fertilizer conditioners.

Beans are nutrient-demanding due to their superficial root system and reduced crop cycle (Fageria \& Souza, 1995). It is, therefore, a good option to test the nutrient extraction capacity, aiming specifically at nutrients contained in alternative sources of soil fertilization.

Soil remineralization, which consists in the use of ground rock in agriculture, can reduce acidity, increase the availability of soil nutrients to plants, stimulate microbial activity, and increase agricultural production (Silva et al., 2012). Several studies have been carried out to evaluate the effect of remineralizers on soils (Melo et al., 2012; Lopes et al., 2014).

The low solubility of minerals hinders their use as a nutrient source (Van Straaten, 2006), especially for short-cycle crops. Ferreira et al. (2009) evaluated the use of basalt powder as a source of nutrients for the common bean crop and concluded that ground basalt did not affect yield and did not alter leaf macroand micronutrient contents, which were maintained at crop sufficiency levels.

Vinasse comes mainly from the production of alcohol in a ratio that normally varies from 12 to 15 liters of vinasse for each liter of ethanol produced (Ferraz Júnior et al., 2016). Due to its acid character $(\mathrm{pH}$ around 4), the vinasse can solubilize minerals contained in remineralizers. Lopes et al. (2014), in a trial with diabase powder, observed greater availability of nutrients in vinasse treatments.

Soil cover crops may also be an alternative to improve the solubilization of minerals contained in remineralizers since they modify the soil microbiota (Buzinaro et al., 2009), stimulate mycorrhizal fungi (Rubido et al., 2017) and can modify the rhizosphere $\mathrm{pH}$ through the release of root exudates (Grayston et al., 1997). Barroti \& Nahas (2000) evaluated the effect of different plant species on the total microbial and phosphate-solubilizing population and concluded that solubilizing bacteria are favored by the planting of brachiaria (Urochloa spp.) without fertilization or associated with soil liming.

Based on the hypothesis that cover crops and vinasse can accelerate the release of elements contained in remineralizers and stimulate the development of crops, the objective of this study was to evaluate the biometric parameters and leaf nutrient contents of common bean in succession to cover crops, as a function of the application of remineralizer doses (basalt powder) and vinasse.

\section{Material and methods}

The experiment was conducted from January to May 2015, in a greenhouse located at $22^{\circ} 18^{\prime} 53.2^{\prime \prime} \mathrm{S}$ and $47^{\circ} 23^{\prime} 00.9^{\prime \prime} \mathrm{W}$, at an altitude of $600 \mathrm{~m}$, in the municipality of Araras (SP). The soil used was a Red Latosol with clayey texture (Oliveira et al., 1982), collected in an area under conventional cultivation, at 0-0.20 m depth. The chemical and physical analyses, according to Raij et al. (2001) and Camargo et al. (2009), respectively, indicated: $510 \mathrm{~g} \mathrm{~kg}^{-1}$ clay; $320 \mathrm{~g} \mathrm{~kg}^{-1}$ sand; $170 \mathrm{~g} \mathrm{~kg}^{-1}$ silt; $\mathrm{pH}\left(\mathrm{CaCl}_{2}\right)$ 5.4; $28 \mathrm{mmol}_{\mathrm{c}} \mathrm{dm}^{-3}$ potential acidity; $19 \mathrm{mg} \mathrm{dm}^{-3} \mathrm{P}$ (resin); $5.4 \mathrm{mmol}_{\mathrm{c}} \mathrm{dm}^{-3} \mathrm{~K} ; 72 \mathrm{mmol}_{\mathrm{c}} \mathrm{dm}^{-3} \mathrm{Ca} ; 14 \mathrm{mmol}_{\mathrm{c}} \mathrm{dm}^{-3}$ $\mathrm{Mg}$; and $37 \mathrm{~g} \mathrm{dm}^{-3}$ organic matter. The calculation of cation exchange capacity (CEC) and base saturation (V-value) indicated $118.9 \mathrm{mmol}_{\mathrm{c}} \mathrm{dm}^{-3}$, and $76 \%$, respectively.

The experimental design was a randomized complete block design in a $4 \times 4 \times 2$ factorial scheme, with three replications. The first factor (F1) was remineralizer doses $\left(0,2,4\right.$, and $8 \mathrm{t} \mathrm{ha}^{-1}$ basalt powder). The second factor (F2) was the cover crops crotalaria (Crotalaria juncea), millet (Pennisetum glaucum) and brachiaria (Urochloa cv. ruziziensis), and no cover crops (control). The third factor (F3) was the presence or absence of vinasse $\left(200 \mathrm{~m}^{3} \mathrm{ha}^{-1}\right.$ and $0 \mathrm{~m}^{3} \mathrm{ha}^{-1}$, respectively).

The remineralizer, collected in Cordeirópolis (SP), presented $50.31 \% \mathrm{SiO}_{2} ; 12.63 \% \mathrm{Fe}_{2} \mathrm{O}_{3} ; 0.84 \%$ $\mathrm{K}_{2} \mathrm{O} ; 13.94 \% \mathrm{Al}_{2} \mathrm{O}_{3} ; 2.24 \% \mathrm{Na}_{2} \mathrm{O} ; 6.91 \% \mathrm{MgO} ; 10.16 \%$ $\mathrm{CaO}$; and $0.09 \% \mathrm{P}_{2} \mathrm{O}_{5}$ in the chemical characterization of hand samples by inductively coupled plasma-mass spectrometry (ICP-MS) and inductively coupled plasma-atomic emission spectrometry (ICP-AES). The collected remineralizer was sieved until a material of size less than or equal to $0.3 \mathrm{~mm}$ was obtained.

The vinasse used, from molasses must, was collected in a sugar and alcohol production plant in Pirassununga (SP) and kept frozen until its use. The chemical analysis, according to Rodella (1983), indicated $\mathrm{pH}$ in water $(1: 2.5) 4 ; 4.80 \mathrm{~kg} \mathrm{~m}^{-3} \mathrm{C} ; 0.50 \mathrm{~kg} \mathrm{~m}^{-3}$ $\mathrm{N} ; 0.117 \mathrm{~kg} \mathrm{~m}^{-3} \mathrm{P}_{2} \mathrm{O}_{5} ; 3.25 \mathrm{~kg} \mathrm{~m}^{-3} \mathrm{~K}_{2} \mathrm{O} ; 10.92 \mathrm{~kg} \mathrm{~m}^{3}$ $\mathrm{CaO} ; 1.24 \mathrm{~kg} \mathrm{~m}^{-3} \mathrm{MgO}$; and $2.58 \mathrm{~kg} \mathrm{~m}^{-3} \mathrm{SO}_{4}$.

Polyethylene pots were used, in which $4.5 \mathrm{dm}^{3}$ of soil were initially added. Then, the remineralizer was mixed to $0.5 \mathrm{dm}^{3}$ of soil and added to the pots, completing the volume of $5 \mathrm{dm}^{3}$. Subsequently, the vinasse was applied according to the treatments. After seven days of incubation, the cover crops were sown in the ratio of $0.1 \mathrm{~g}$ crotalaria per pot, $0.056 \mathrm{~g}$ millet per pot and $0.064 \mathrm{~g}$ brachiaria per pot. The cover crops were conducted up to 45 days after incubation (DAl) and then cut close to the soil, maintaining only the roots until the end of the experiment. 
At $45 \mathrm{DAl}$, and after cutting the cover crops, in each pot were sown 10 seeds of common bean (Phaseolus vulgaris L.) cv. BRS Talismã, with an average cycle of 85 days. Thinning was performed at $V_{2}$ stage (unfolding of the primary leaves), leaving two plants per pot.

At 90 DAl, corresponding to 40 days after emergence (DAE) of the bean plants, the Falker chlorophyll index (FCl) was evaluated using the ClorofiLOG $^{\circledR}$ device (Falker, 2008). Reading was performed on the third expanded trifoliate leaf of the two plants of the pot, with reading in the middle third of the leaf; later, the pot mean was calculated.

At $R_{6}$ stage (full bloom), i.e., at 105 DAl and 55 DAE of the common bean, the plants were cut close to the soil, with determination of the following variables: leaf area index (LAl), in $\mathrm{cm}^{2}$ per plant; plant height (h), in centimeters; and shoot dry matter (SDM), in kilograms. All leaves of each plant were submitted to a photoelectric reader, using the Portable Area Meter model $\mathrm{LI}-3000 \mathrm{C}^{\circledR}$, to determine the total leaf area (LA total). The total leaf area value obtained was divided by the soil area (SA) occupied by the plant to determine the leaf area index (LAI), given by LAtota/SA.

Subsequently, common bean plants were kept at $65{ }^{\circ} \mathrm{C}$ in a forced air circulation oven until constant weight. Then, the leaves were ground, and the total contents of $\mathrm{N}, \mathrm{P}, \mathrm{K}, \mathrm{Ca}, \mathrm{Mg}$, and $\mathrm{S}$ were determined, according to Malavolta et al. (1997).
For the purpose of analysis of variance, leaf $\mathrm{K}$ data were transformed by the function $\mathrm{x}=\sqrt{x}$, given that the assumptions of the mathematical model were not met.

Using the software Assistat (Silva \& Azevedo, 2016), the data obtained were submitted to analysis of variance and, later, when significant at $1 \%$ by the F-test, regression analyses were performed for plant height, shoot dry matter, leaf area index and $\mathrm{N}, \mathrm{P}, \mathrm{K}$, $\mathrm{Ca}, \mathrm{Mg}$ and $\mathrm{S}$ contents in common bean plants. The means of the leaf area index of common bean were compared by the Scott-Knott test $(p<0.05)$.

\section{Results and discussion}

\section{Biometric parameters of common bean}

There was effect of cover crops (F2) on all biometric parameters of vinasse (F3) on common bean height, and of basalt powder doses (F1) on height and LAI. The triple interaction between F1xF2xF3 was significant only for common bean height, while the F1xF2 interaction was significant for SDM, and the F2xF3 interaction was significant for LAI. In the present study, the interaction between remineralizer and vinasse showed no significant effect for any of the biometric attributes of common bean studied (Table 1).

Table 1 - Mean square values (MS), F statistics, $F$ test $(\mathrm{Pr}>\mathrm{F})$ and coefficient of variation (CV) for the biometric parameters on the occasion of the full flourishing of bean BRS MG Talisman, grown in succession to cover plants (F2) and as a function of remineralizer (F1) and vinasse (F3) doses, in greenhouse in Araras (São Paulo).

\begin{tabular}{|c|c|c|c|c|c|c|c|}
\hline Variation causes & $\mathrm{F} 1$ & F2 & F3 & F1xF2 & $\mathrm{F} 1 \times \mathrm{F} 3$ & F2xF3 & $\mathrm{F} 1 \times \mathrm{F} 2 \mathrm{xF} 3$ \\
\hline Degree of freedom & 3 & 3 & 1 & 9 & 3 & 3 & 9 \\
\hline & \multicolumn{7}{|c|}{ Height (cm) } \\
\hline MS & 165.69 & 312.41 & 1419.88 & 16.70 & 41.96 & 25.82 & 100.13 \\
\hline $\mathrm{F}$ & 5.16 & 9.73 & 44.23 & 0.52 & 1.31 & 0.80 & 3.12 \\
\hline \multirow[t]{2}{*}{$\begin{array}{l}\mathrm{Pr}>\mathrm{F} \\
\mathrm{CV}(\%)\end{array}$} & ** & ** & ** & $\begin{array}{l}\text { ns } \\
13.61\end{array}$ & ns & ns & ** \\
\hline & \multicolumn{7}{|c|}{ Aerial part dry mass (g planta ${ }^{-1}$ ) } \\
\hline MS & 1.86 & 25.83 & 44.95 & 2.22 & 0.72 & 1.58 & 0.57 \\
\hline $\mathrm{F}$ & 1.81 & 25.16 & 43.79 & 2.16 & 0.70 & 1.54 & 0.56 \\
\hline & ns & ** & ** & * & ns & ns & ns \\
\hline \multirow{2}{*}{ CV (\%) } & & & & 9.61 & & & \\
\hline & \multicolumn{7}{|c|}{ Foliar area $\left(\mathrm{cm} \mathrm{cm}^{-2}\right)$} \\
\hline MS & 8384.38 & 41634.27 & 64854.93 & 1212.48 & 1284.91 & 11222.22 & 975.87 \\
\hline $\mathrm{F}$ & 4.58 & 22.76 & 35.45 & 0.66 & 0.70 & 6.13 & 0.53 \\
\hline & ** & ** & ** & ns & ns & ** & ns \\
\hline \multirow{2}{*}{ CV (\%) } & & & & 4.17 & & & \\
\hline & \multicolumn{7}{|c|}{ Falker Chlorophyll index } \\
\hline MS & 4.07 & 66.32 & 26.56 & 17.36 & 7.08 & 13.52 & 13.92 \\
\hline $\mathrm{F}$ & 0.43 & 7.05 & 2.83 & 1.85 & 0.75 & 1.44 & 1.48 \\
\hline $\begin{array}{l}\mathrm{Pr}>\mathrm{F} \\
\mathrm{CV}(\%)\end{array}$ & ns & ** & ns & $\begin{array}{l}\text { ns } \\
6.59\end{array}$ & ns & ns & ns \\
\hline
\end{tabular}

**, * - significant by $\mathrm{F}$ test $1 \%$ and $5 \%$, respectively; ns - non significant by $\mathrm{F}$ test.

To visualize the significance of the triple interaction in the attribute common bean height, the unfolding was done considering the treatments without and with vinasse application. It was observed that 
vinasse treatments provided higher plant heights than treatments without vinasse (Figure 1). The highest growth of bean plants in the presence of vinasse possibly occurred because vinasse presents a significant amount of $\mathrm{Ca}$, ion responsible for the vegetative growth of bean (Leal \& Prado, 2008). It should be noted that in the soil used in the experiment there was already an adequate amount of $\mathrm{Ca}$ (Souza et al., 2017). It was also observed that the application of vinasse influenced the growth of common bean plants when associated with cover crops, as a function of remineralizer doses and when compared to the control (Figure 1b).
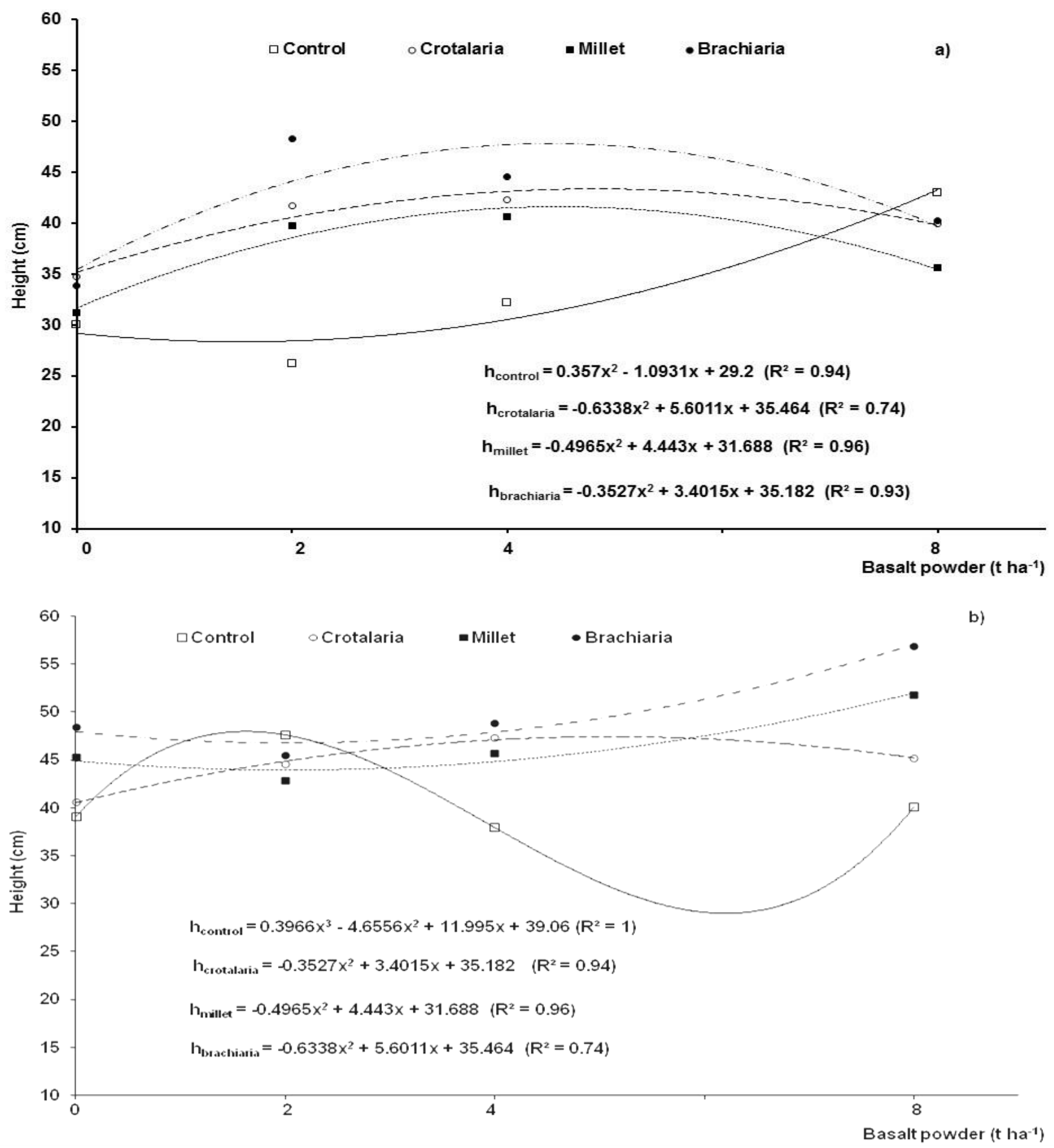

Figure 1 - Bean plant height (h), cultivar Talisman, grown in succession to cover plants, on the rates of basalt powder applied: a) without vinasse and b) with vinasse.

Grasses (millet and brachiaria) were more efficient on the height attribute, with higher plant height $(56.9 \mathrm{~cm})$ in the treatment with brachiaria, vinasse, and the dose of $8 \mathrm{t} \mathrm{ha}^{-1}$ basalt powder (Figure 1b). The association between only remineralizer doses and cover crops was less beneficial when compared to vinasse treatments, with an equal effect between doses and cover crops. 
Evaluating the height of this same bean variety under field conditions, Vieira et al. (2008) found that cv. Talismã reached a maximum height of $100 \mathrm{~cm}$ at $70 \mathrm{DAE}$. Considering that the measure here was made at $55 \mathrm{DAE}$, it is estimated that the maximum remineralizer dose of $8 \mathrm{tha}^{-1}$ and in the presence of vinasse, in succession to brachiaria, would not be enough to allow the bean plants reached their maximum height.

The unfolding of the double interaction remineralizer $x$ cover crops (Figure 2) showed that the
SDM of the common bean varied according to the type of cover crop; all of which had a greater effect than the control. Crotalaria and brachiaria treatments showed an increase in bean SDM, but with a small variation between the minimum and the maximum dose. As in the previous variable, brachiaria presented positive results, indicating that grasses, mainly brachiaria, are good alternative methods capable of maintaining the adequate development of common bean, similar to conventional cultivation.

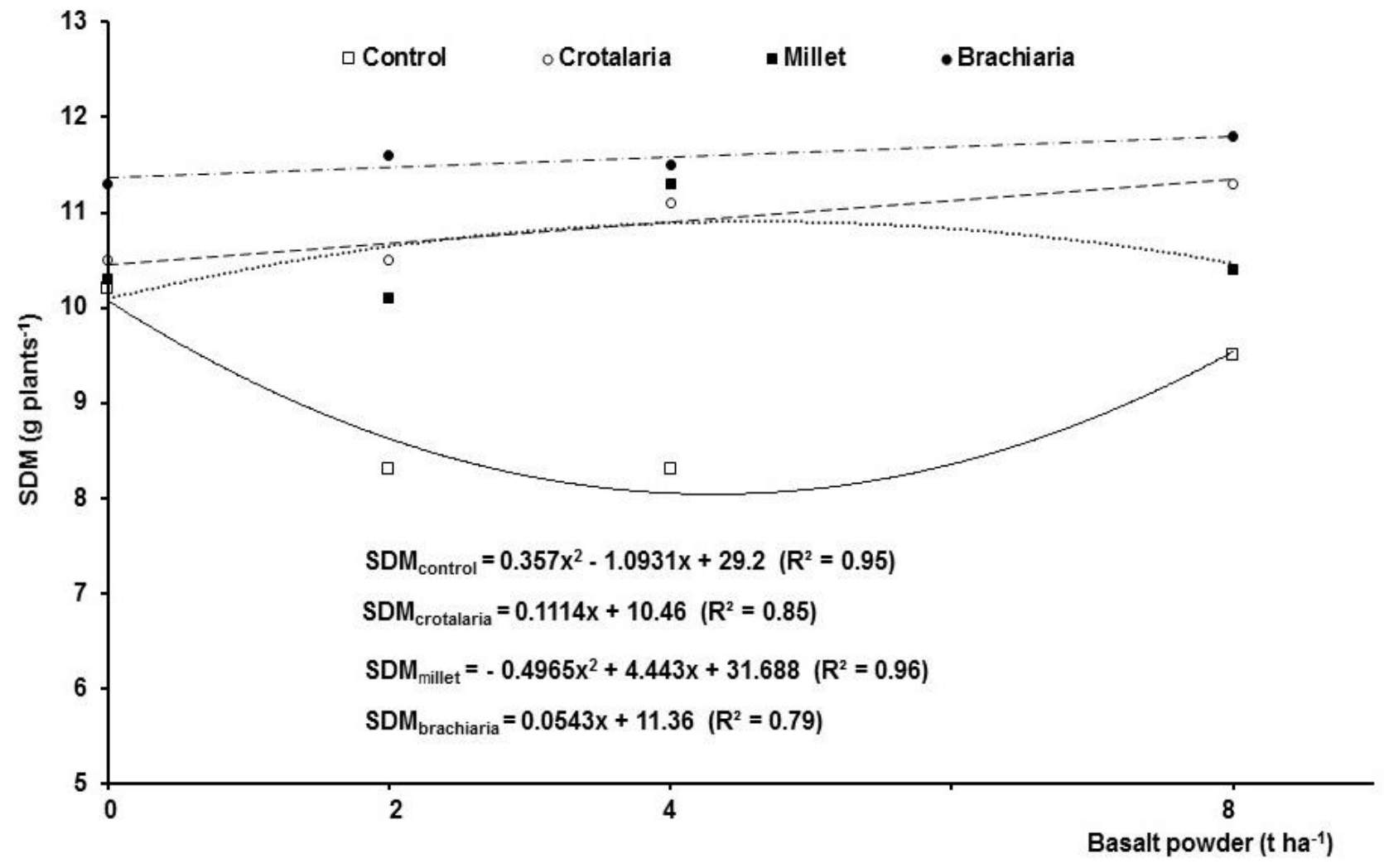

Figure 2 - Shoot dry mass of bean plants (SDM), cultivar Talisman, cultivated in succession to cover plants, as a function of doses of basalt powder.

The results observed in the present study were similar to those found by Vieira et al. (2008), who, evaluating the growth of common bean cv. BRS-MG Talismã under different cropping systems, obtained dry matter accumulation between 10 and $11.66 \mathrm{~g}$ per plant. In comparison to Pereira et al. (2015), who observed an accumulation of $7.43 \mathrm{~g}$ per plant when evaluating the influence of organic fertilizer doses on the production components and yield of the bean crop, the SDM accumulation observed here remained at higher levels.

The unfolding of the double interaction between the type of cover and the presence or absence of vinasse indicated that only the LAl of common bean plants grown in succession to millet did not present any difference in relation to the presence of vinasse; but in comparison with the control treatment, millet increased the LAl of common bean. In the other types of cover, including the control (without cover), vinasse provided an increase in LAI (Figure 3), possibly due to the same reason for bean height variation in vinasse treatments (significant amount of $\mathrm{Ca}$, ion responsible for vegetative growth). Among the cover crops, the best response to the association with vinasse was that with crotalaria, which showed an increase of $42 \%$ in relation to the treatment without vinasse.

Considering the observed results for plant height and leaf area index, which are yield-related traits, it can be estimated that the association of vinasse with remineralizer doses has the potential to increase the yield of this crop.

\section{Leaf nutrient content}

There was an effect of remineralizer $(\mathrm{F} 1)$ on all leaf macronutrients, with the exception of $\mathrm{K}$, and of cover types (F2) on $\mathrm{P}, \mathrm{K}, \mathrm{Ca}$ and $\mathrm{Mg}$. The vinasse factor (F3) had an effect on all leaf macronutrients. Macronutrients $\mathrm{K}, \mathrm{Ca}, \mathrm{Mg}$ and $\mathrm{S}$ presented triple interaction, whereas $\mathrm{N}$ and $\mathrm{P}$ showed a double interaction between remineralizer and vinasse (Table 2). 


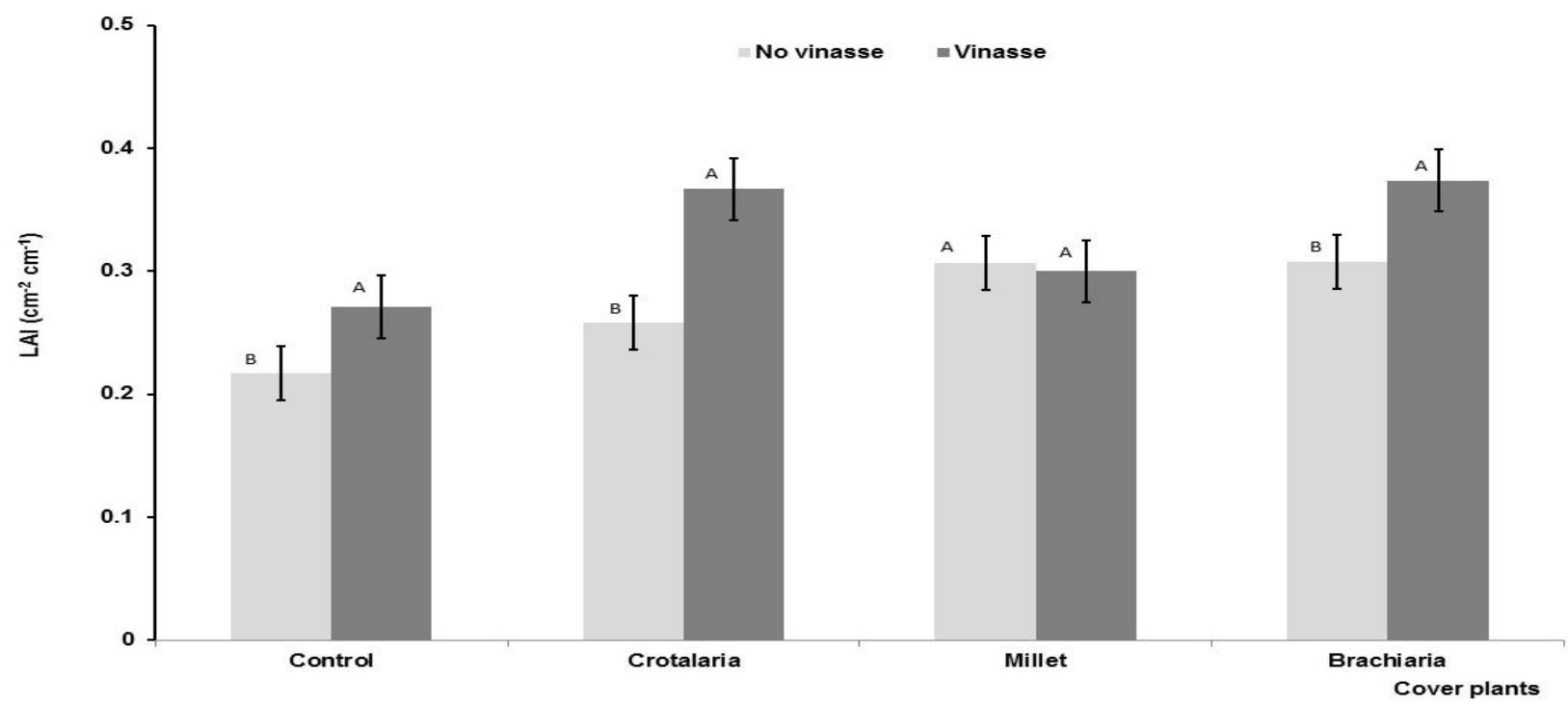

Figure 1 - Leaf area index of bean plants (LAI), cultivar Talisman, cultivated in succession to cover plants, according to the application of $0 \mathrm{~m}^{3} \mathrm{ha}^{-1}$ (no vinasse) or $200 \mathrm{~m}^{3} \mathrm{ha}^{-1}$ of vinasse. Means followed by similar letters do not differ from each other, by the Scott-Knott test $(p<0.05)$.

Table 2 - Mean square values (MS), $F$ statistics, probability of significance of $F(\operatorname{Pr}>F)$ and coefficient of variation (CV) for nutrient content in foliar tissue of bean, cultivar Talisman, grown in succession to cover plants (F2) and as a function of remineralizer (F1) and vinasse (F3) doses, in greenhouse in Araras (São Paulo).

\begin{tabular}{|c|c|c|c|c|c|c|c|}
\hline Variation causes & F1 & F2 & F3 & F1xF2 & F1xF3 & F2xF3 & F1xF2xF3 \\
\hline Degree of freedom & 3 & 3 & 1 & 9 & 3 & 3 & 9 \\
\hline & \multicolumn{7}{|c|}{$\mathrm{N}\left(\mathrm{g} \mathrm{kg}^{-1}\right)$} \\
\hline MS & 277.95 & 55.325 & 1391.57 & 34.69 & 271.25 & 17.99 & 45.76 \\
\hline & 10.78 & 2.18 & 54.94 & 1.37 & 10.71 & 0.71 & 1.81 \\
\hline $\operatorname{Pr}>\mathrm{F}$ & & ns & & & ** & ns & ns \\
\hline & \multicolumn{7}{|c|}{15.04} \\
\hline & \multicolumn{7}{|c|}{$P\left(g_{k g}^{-1}\right)$} \\
\hline MS & 0.57 & 1.28 & 1.82 & 0.11 & 0.29 & 0.06 & 0.19 \\
\hline $\mathrm{F}$ & 5.99 & 13.38 & 19.04 & 1.10 & 3.04 & 0.66 & 1.94 \\
\hline $\operatorname{Pr}>\mathrm{F}$ & ** & ** & ** & ns & * & ns & ns \\
\hline CV (\%) & \multicolumn{7}{|c|}{21.30} \\
\hline & \multicolumn{7}{|c|}{ (1) $\mathrm{K}\left(\mathrm{g} \mathrm{kg}^{-1}\right)$} \\
\hline MS & 0.01 & 0.023 & 0.17 & 0.01 & 0.13 & 0.01 & 0.02 \\
\hline $\mathrm{F}$ & 1.2376 & 2.94 & 20.85 & 1.2767 & 16.05 & 1.79 & 2.12 \\
\hline $\operatorname{Pr}>\mathrm{F}$ & ns & & ** & ns & ** & ns & t \\
\hline CV (\%) & \multirow{2}{*}{\multicolumn{7}{|c|}{$\frac{14.75}{\mathrm{Ca}\left(\mathrm{kg}^{-1}\right)}$}} \\
\hline & & & & & & & \\
\hline MS & 115.18 & 34.94 & 1135.38 & 12.87 & 102.43 & 19.35 & 16.45 \\
\hline & 15.38 & 4.67 & 151.60 & 1.72 & 13.68 & 2.58 & 2.20 \\
\hline $\mathrm{Pr}>\mathrm{F}$ & ** & & ** & ns & ** & ns & \\
\hline CV (\%) & \multicolumn{7}{|c|}{20.00} \\
\hline & \multicolumn{7}{|c|}{$\operatorname{Mg}\left(\mathrm{g} \mathrm{kg}^{-1}\right)$} \\
\hline MS & 1.10 & 1.78 & 7.19 & 0.31 & 0.89 & 0.24 & 0.81 \\
\hline & 5.13 & 8.32 & 33.67 & 1.44 & 4.15 & 1.14 & 3.78 \\
\hline $\mathrm{Pr}>\mathrm{F}$ & $* *$ & $* *$ & ** & & ** & ns & ** \\
\hline CV(\%) & \multicolumn{7}{|c|}{$\frac{24.03}{S\left(a k q^{-1}\right)}$} \\
\hline & \multicolumn{7}{|c|}{$\mathrm{S}\left(\mathrm{g} \mathrm{kg}^{-1}\right)$} \\
\hline MS & 1.64 & 0.01 & 3.21 & 0.23 & 0.40 & 0.21 & 0.12 \\
\hline $\mathrm{F}$ & 30.34 & 0.17 & 59.49 & 4.17 & 7.31 & 3.96 & 2.14 \\
\hline $\mathrm{Pr}>\mathrm{F}$ & ** & ns & ** & 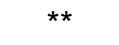 & ** & * & * \\
\hline CV (\%) & \multicolumn{7}{|c|}{22.37} \\
\hline
\end{tabular}

**, * significant by $\mathrm{F}$ test $1 \%$ and $5 \%$ respectively; ns - non significant by $\mathrm{F}$ test. ${ }^{(1)}$ Data transformed by $\sqrt{x}$. 
The unfolding of the interaction remineralizer $x$ vinasse revealed that the $\mathrm{N}$ and $\mathrm{P}$ contents in the vinasse treatments were lower than in the treatments without vinasse (Figure 4). This result possibly occurred because the addition of vinasse influences microbial activity (Ferreira \& Monteiro, 1987), and may caused temporary immobilization of $\mathrm{N}$, which would explain the lower leaf $\mathrm{N}$ uptake in treatments with vinasse addition. $\mathrm{N}$ content usually correlates with chlorophyll and leaf S contents (Neves et al., 2005), which was not verified in the present work.
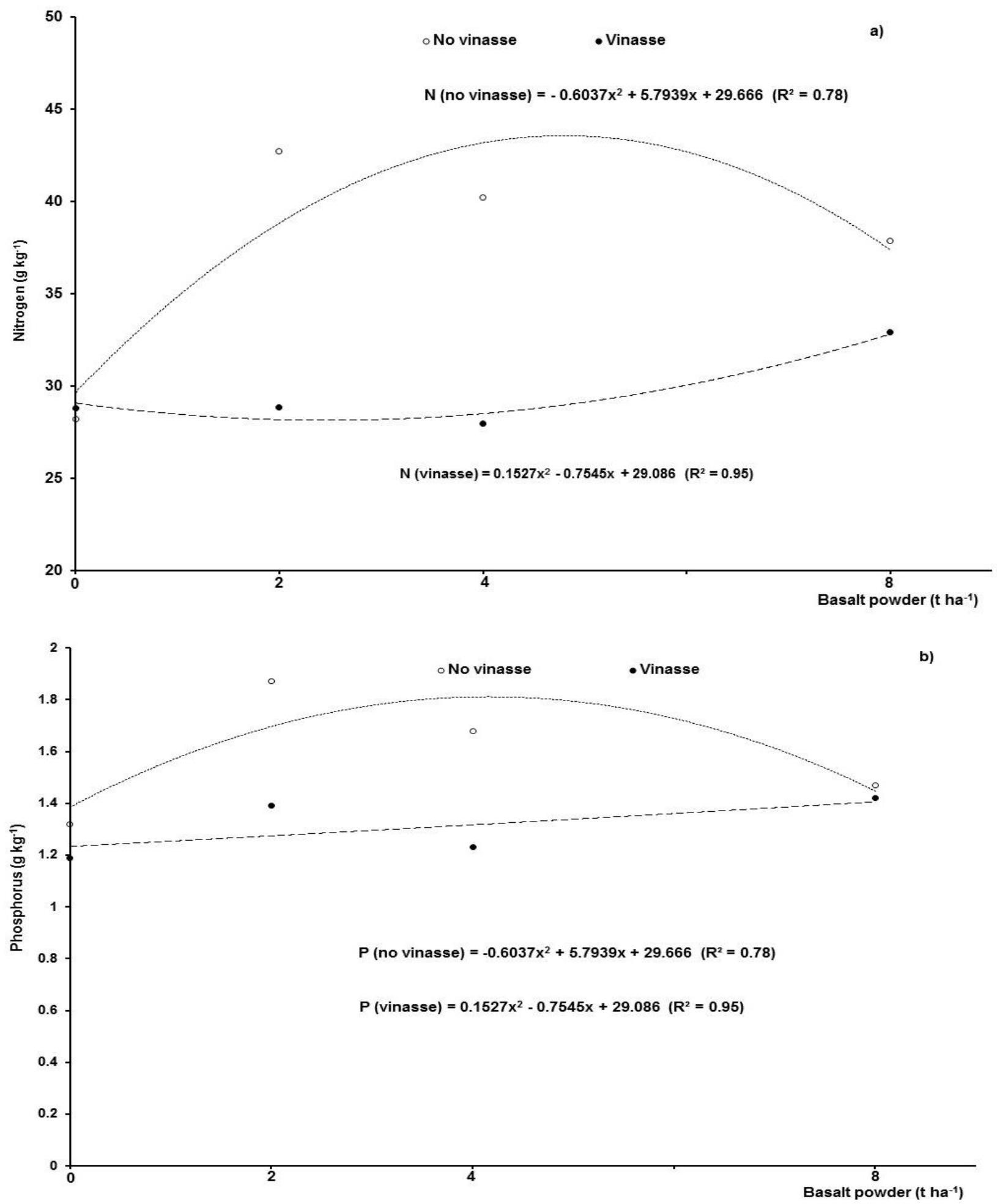

Figure 4 - Nutrient content, in $\mathrm{g} \mathrm{kg}^{-1}$, in the shoot dry mass of plants of bean, cultivar Talisman, cultivated in greenhouse in succession to cover plants, according to doses of basalt powder and of vinasse: a) nitrogen levels $(\mathrm{N})$, and (b) phosphorus levels $(\mathrm{P})$. 
For the same cultivar, under no-tillage system, Vieira (2006) observed values of $38.67 \mathrm{~g} \mathrm{~kg}^{-1}$ for $\mathrm{N}$, lower than those observed in the present study in the treatments without addition of vinasse and with addition of 2 and $4 \mathrm{t} \mathrm{ha}^{-1}$ remineralizer. On the other hand, the $P$ levels observed in this work, both in the treatments with and without vinasse, were below those observed by Vieira (2006) for cv. Talismã in no-tillage; the author obtained an average value of $3.02 \mathrm{~g} \mathrm{~kg}^{-1}$, although soil $\mathrm{P}$ contents were adequate to the crop. It should be emphasized that the applied remineralizer did not contain $\mathrm{N}$ and had very low $\mathrm{P}$ contents. Therefore, the contents of these nutrients observed in bean leaves, in treatments with and without vinasse application, reflect an indirect effect of the remineralizer. Silva et al. (2012) observed an effect of rock powder on soil $\mathrm{pH}$, which may increase the availability of $\mathrm{P}$ to plants.

The unfolding of the triple interaction remineralizer $x$ cover crops $x$ vinasse showed that the contents of K (Figure 5b), Ca (Figure 6b), and Mg (Figure 7b) responded negatively to the application of vinasse, and increased doses of remineralizer.
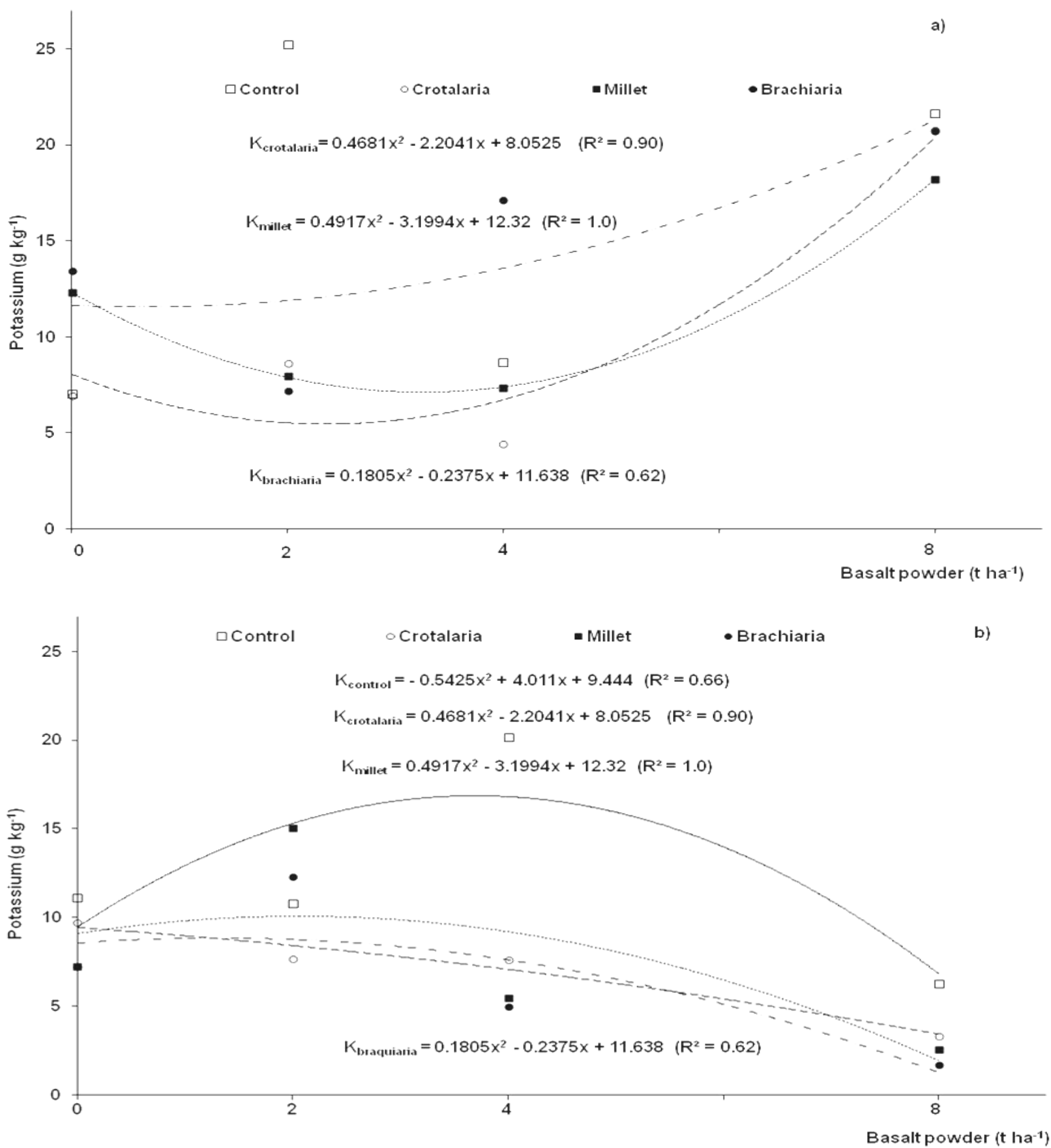

Figure 5 - Potassium contents $(\mathrm{K})$, in $\mathrm{g} \mathrm{kg}^{-1}$, in the shoot dry mass of plants of bean, cultivar Talisman, cultivated in greenhouse in succession to cover plants, according to doses of basalt powder: a) without vinasse, and b) with vinasse. 
In the absence of vinasse, there was a trend of increase of $\mathrm{K}$ content in bean leaves as a function of increasing doses of remineralizer, and effect of cover types, with emphasis on brachiaria (Figure 5a). On the other hand, $\mathrm{Ca}$ and $\mathrm{Mg}$ contents were higher in the presence of $4 \mathrm{t} \mathrm{ha}^{-1}$ remineralizer (Figures $6 \mathrm{a}$ and $7 \mathrm{a}$ ). In the treatments with vinasse (Figures $5 b, 6 b$ and $7 b$ ), the increase of the doses of remineralizer provided a decrease in the concentrations of leaf $\mathrm{K}, \mathrm{Ca}$ and $\mathrm{Mg}$ in all cover types.
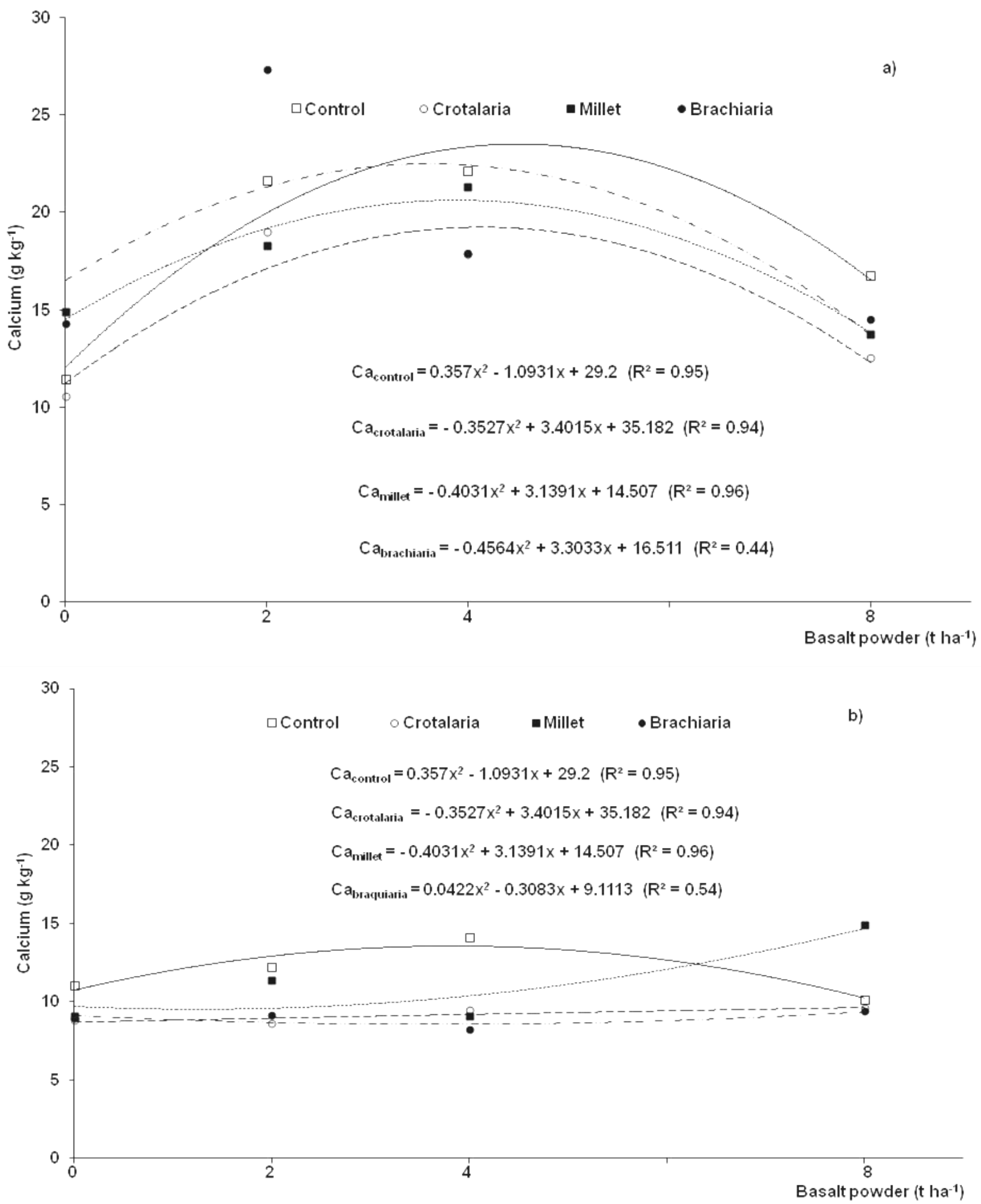

Figure 6 - Calcium contents $(\mathrm{Ca})$, in $\mathrm{g} \mathrm{kg}^{-1}$, in the shoot dry mass of plants of bean, cultivar Talisman, cultivated in greenhouse in succession to cover plants, according to doses of basalt powder: a) without vinasse, and b) with vinasse. 
The results observed in the remineralizer dose of $8 \mathrm{tha}^{-1}$ in the treatments without vinasse were similar to those obtained by Vieira (2006), who evaluated the same cultivar in different cropping systems and observed a concentration, in no-tillage system, of $20.48 \mathrm{~g}$ of leaf $\mathrm{K}$ per plant at flowering. Ferreira et al. (2009), working with basalt powder as a fertilizer source for common bean, did not observe a decrease in Ca content with the application of increasing doses
(2.5, 5 and $\left.10 \mathrm{tha}^{-1}\right)$ of the remineralizer. The influence of cover crops on leaf $\mathrm{Ca}$ concentrations was small for most treatments. Considering that the appropriate range of leaf $\mathrm{Ca}$ for bean is 20 to $24 \mathrm{~g} \mathrm{~kg}^{-1}$ (Raij et al., 1997), and that Vieira (2006) indicates that the bean crop increasingly absorbed $\mathrm{Ca}$ up to 68 days after emergence, the results observed in this work for the lowest doses of basalt powder without addition of vinasse were adequate.
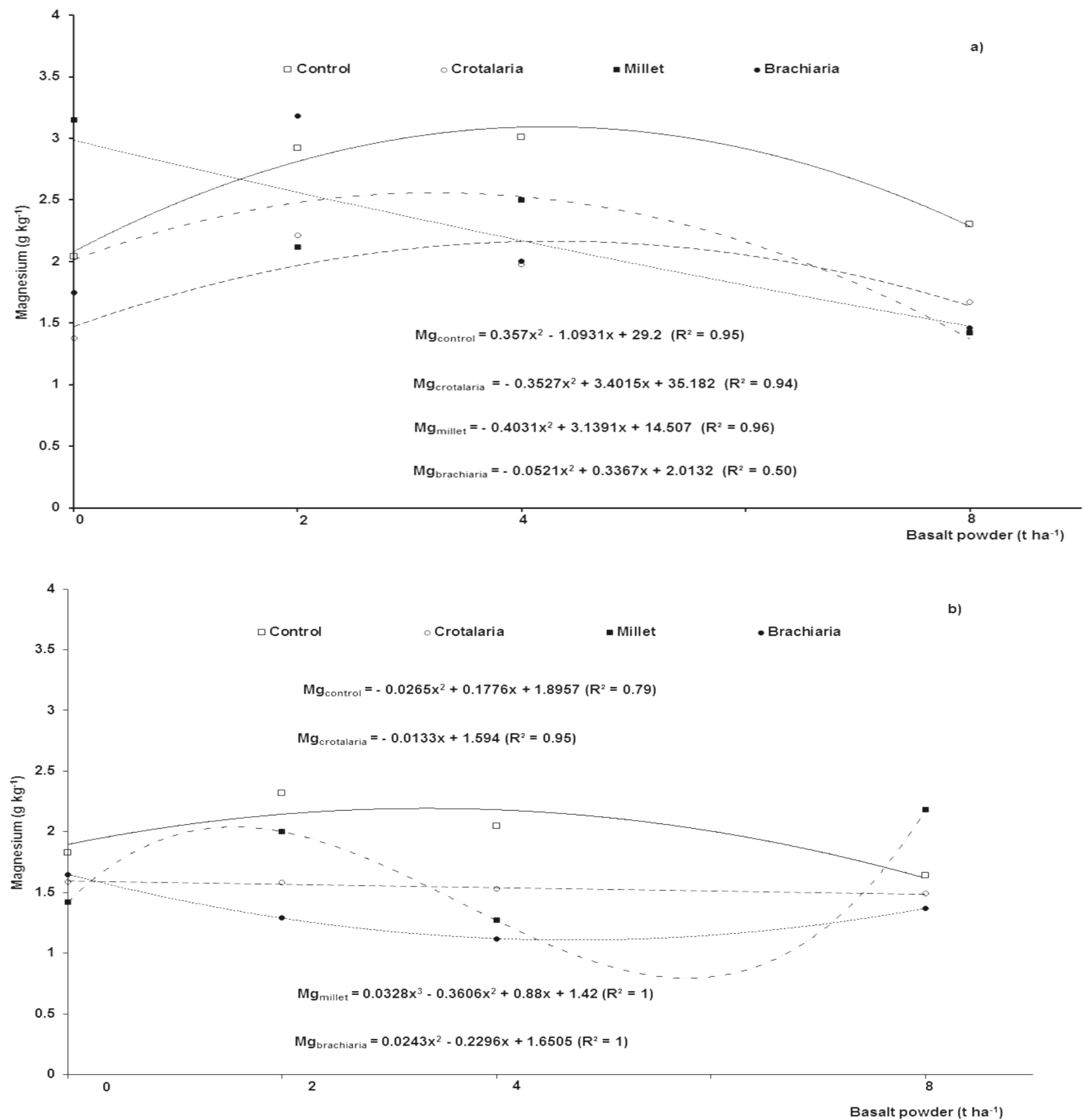

Figure 7 - Magnesium contents (Mg), in $\mathrm{g} \mathrm{kg}^{-1}$, in the shoot dry mass of plants of bean, cultivar Talisman, cultivated in greenhouse in succession to cover plants, according to doses of basalt powder: a) without vinasse, and b) with vinasse.

The application of remineralizer without vinasse yielded leaf $\mathrm{Mg}$ contents close to those suitable for common bean, in the range of 2.5 to $5.0 \mathrm{~g} \mathrm{~kg}^{-1}$, as indicated by Raij et al. (1997). Ferreira et al. (2009), evaluating the effects of a basalt powder as a source of nutrients for the bean crop, verified results of $6.4 ; 6.6$; 
and $7.2 \mathrm{~g} \mathrm{~kg}^{-1}$ leaf $\mathrm{Mg}$ at the doses of 2.5; 5; and $10 \mathrm{t} \mathrm{ha}^{-1}$, respectively, values well above those found in the present work.

The amount of $\mathrm{K}, \mathrm{Ca}$, and $\mathrm{Mg}$ from the vinasse and remineralizer added to the soil, which already had adequate amounts of these elements for bean cultivation, may have caused imbalance of these elements, influencing their absorption by the bean.

This aspect is of great importance in the transition from conventional production systems to agroecological systems. According to Gleissman (2005), the agroecological transition does not consist simply in replacing external inputs, but rather is a process capable of implementing multilinear and gradual changes in the forms of agroecosystem management.
Soils grown in conventional systems, receiving industrial fertilizers for several years, may not respond in the short term to the application of doses of remineralizers, as observed in this work.

The consumption of soil nutrients by the cover crops may have been another factor responsible for the lower contents of bean leaf nutrients due to the application of vinasse. Differently from the other leaf macronutrients analyzed, the S content in the vinasse treatments was generally higher than in the treatments without vinasse (Figure 8). The treatments that received vinasse presented increasing results with the application of remineralizer, except for brachiaria (Figure 8b).
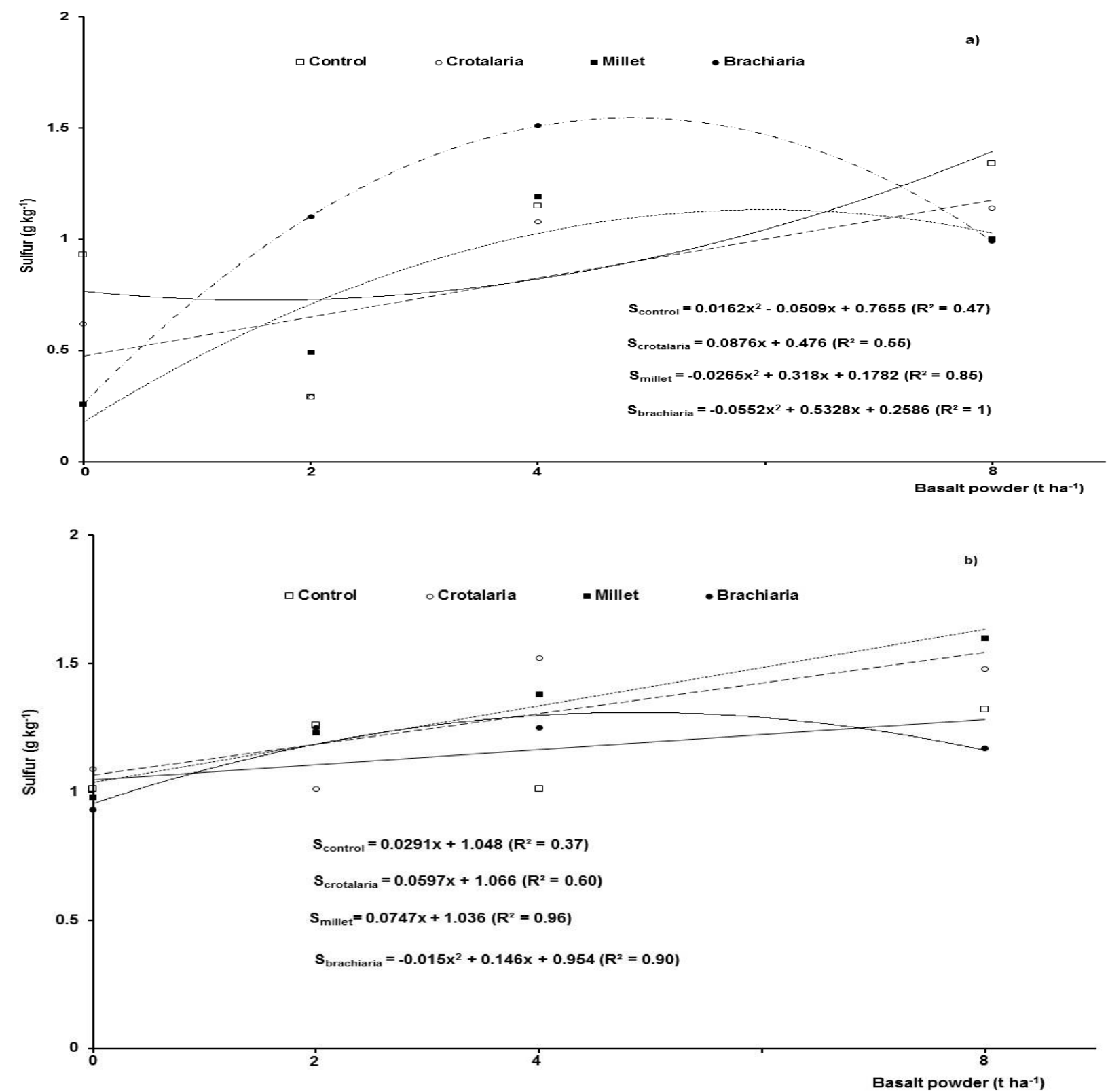

Figure 8 - Sulfur content (S), in $\mathrm{g} \mathrm{kg}^{-1}$, in the shoot dry mass of plants of bean, cultivar Talisman, cultivated in greenhouse in succession to cover plants, according to doses of basalt powder: a) without vinasse, and b) with application of vinasse. 
The $S$ accumulation in leaves of common bean cv. Talismã reached a maximum of about $1.5 \mathrm{~g} \mathrm{~kg}^{-1}$ at the remineralizer dose of $8 \mathrm{t} \mathrm{ha}^{-1}$ with vinasse, in succession to crotalaria and millet plants, while in succession to brachiaria the maximum was reached at the dose of $4 \mathrm{t} \mathrm{ha}^{-1}$. These results were lower than those observed by Vieira (2006), who verified $2.07 \mathrm{~g} \mathrm{~kg}^{-1}$ of leaf $\mathrm{S}$ accumulation at flowering for common bean cv. Talismã. The application of remineralizer kept the $S$ contents close to those suitable for the crop (2.0 to $3.0 \mathrm{~g} \mathrm{~kg}^{-1}$ ), according to Raij et al. (1997), although the bean was only in its flowering stage.

Although $516 \mathrm{~kg} \mathrm{ha}^{-1} \mathrm{SO}_{4}$ were applied through the vinasse, the $\mathrm{S}$ contents were not higher than in the treatments without vinasse. Ambrosano et al. (1996) recommend the application of $30 \mathrm{~kg} \mathrm{ha}^{-1} \mathrm{~S}$ in bean crops with yield goals above $2,000 \mathrm{~kg} \mathrm{ha}^{-1}$, regardless of the element content in the soil. This reinforces the hypothesis that the soil S content (adequate amount in the soil plus the application through the vinasse and remineralizer) impaired the absorption of elements by the bean.

\section{Conclusions}

Cover crops, vinasse and remineralizer provide increase height of common bean plants at stage R6 (full bloom), with emphasis for brachiaria in the treatment with vinasse and $8 \mathrm{t} \mathrm{ha}^{-1}$ basalt powder. The interaction between cover crops, vinasse and remineralizer also affects the $\mathrm{K}, \mathrm{Ca}, \mathrm{Mg}$ and $\mathrm{S}$ contents in bean leaves. However, the vinasse has a positive effect only on $\mathrm{S}$ content. Remineralizer doses associated to cover crops, without vinasse, provide differences in the leaf macronutrient contents of common bean, with satisfactory crop sufficiency levels, considering the stage R6 (full bloom).

\section{Acknowledgements}

To CAPES, for granting the Master's scholarship to the first author.

\section{References}

Ambrosano EJ, Tanaka RT, Mascarenhas HAA, Rai BV, Quaggio JA, Cantarella H (1996) Leguminosas e oleaginosas. In: Raij BV, Cantarella H, Quaggio JA, Furlani AMC (Ed.) Boletim técnico 100 - Recomendações de adubação e calagem para o Estado de São Paulo. IAC e Fundação IAC. p.189-203.

BNDES (2006) Fertilizantes: Uma Visão Global Sintética. BNDES Setorial (24):97-138.

Barroti G, Nahas E (2000) População microbiana total e solubilizadora de fosfato em solo submetido a diferentes sistemas de cultivo. Pesquisa Agropecuária Brasileira 35(10):2043-2050. doi: 10.1590/S0100204X2000001000016.
Buzinaro TN, Barbosa JC, Nahas E (2009). Atividade microbiana do solo em pomar de laranja em resposta ao cultivo de adubos verdes. Revista Brasileira de Fruticultura 31(2):408-415. doi: 10.1590/S010029452009000200014.

Camargo OA, Moniz AC, Jorge JA, Valadares JMAS (2009) Métodos de Análise Química, Mineralógica e Física de Solos do Instituto Agronômico de Campinas. IAC. 77 p.

CONAB (2017a) Séries históricas de área plantada, produtividade e produção, relativas às safras 1976/77 a 2015/16 de grãos, 2001 a 2016 de café, 2005/06 a 2016/17 de cana-de-açúcar. Disponível em: <http://www.conab.gov.br/conteudos.php?a=1252\&t=2 \&Paginaobjcmsconteudos=2\#A_objcmsconteudos\&Pa gina_objcmsconteudos=2\#A_objcmsconteudos $>$.

(Acesso em 03 ago 2017).

CONAB (2017b). Compêndio de Estudos Conab v 5. 22 p. Disponível em: <https://www.conab.gov.br/OlalaCMS/uploads/arquivos/17_01_24_14_49_18_compendio_de_estudos_ conab_-_volume_- 5 2017.pdf >. (Acesso em 03 ago 2017).

Fageria NK, Souza NP (1995) Resposta das culturas de arroz e feijão em sucessão a adubação em solo de cerrado. Pesquisa Agropecuária Brasileira 30(3):359-368.

Falker Automação Agrícola Ltda (2008) Manual do medidor eletrônico de clorofila ClorofiLOG CFL 1030. $4 p$.

Ferraz Júnior ADN, Koyama MH, Araújo Júnior MM, Zaiat M (2016) Thermophilic anaerobic digestion of raw sugarcane vinasse. Renewable Energy 89(C):245-252. doi: 10.1016/j.renene.2015.11.064.

Ferreira ERC, Almeida JA, Mafra AL (2009) Pó de basalto, desenvolvimento e nutrição de feijão comum (Phaseolus vulgaris) e propriedades químicas de um Cambissolo Húmico. Revista de Ciências Agroveterinárias 8(2):111-121.

Ferreira ES, Monteiro AO (1987) Efeitos da vinhaça nas propriedades físicas, químicas e biológicas do solo. Boletim técnico Copersucar (37):3-7.

Gleissman SR (2005) Agroecologia: processos ecológicos em agricultura sustentável. 3a ed, UFRGS. 653p.

Grayston SJ, Vaughan D, Jones D (1997) Rhizosphere carbon flow in trees, in comparison with annual plants: the importance of root exudation and its impact on microbial activity and nutrient availability. Applied Soil Ecology 5(1):29-56. doi: 10.1016/S09291393(96)00126-6. 
IBGE (2017) Levantamento Sistemático da Produção Agrícola - junho 2017. Disponível em <https://sidra.ibge.gov.br/home/lspa/brasil> (Acesso em 03 ago 2017).

Leal RM, Prado RM (2008) Desordens nutricionais no feijoeiro por deficiência de macronutrientes, boro e zinco. Revista Brasileira de Ciências Agrárias 3(4):301-306.

Lopes OMM, Carrilho ENV, Lopes-Assad MLRC (2014) Effect of rock powder and vinasse on two types of soils. Revista Brasileira de Ciência do Solo 38(5):1547-1557. doi: 10.1590/S010006832014000500020.

Malavolta E, Vitti GC, Oliveira SA (1997) Avaliação do estado nutricional das plantas: princípios e aplicações. Potafos. 201p.

Melo VF, Uchôa SCP, Dias FO, Barbosa GF (2012). Doses de basalto moído nas propriedades químicas de um Latossolo Amarelo distrófico da savana de Roraima Acta Amazônica 42(4):471-476. doi: 10.1590/S0044-59672012000400004.

Neves OSC, Carvalho JG, Martins FAD, Pádua TRP, Pinho PJ (2005) Uso do SPAD-502 na avaliação dos teores foliares de clorofila, nitrogênio, enxofre, ferro e manganês do algodoeiro herbáceo. Pesquisa Agropecuária Brasileira 40(5):5. doi: 10.1590/S0100204X2005000500014.

Oliveira JB, Menk JRF, Barbieri JL, Rotta CL, Tremoncoldi W (1982) Levantamento pedológico semidetaIhado do Estado de São Paulo: Quadrícula de Araras. Campinas: Instituto Agronômico. 180 p.

Pereira LB, Arf O, Santos NCB, Oliveira AEZ, Komuro LK (2015) Manejo de adubação na cultura do feijão em sistema de produção orgânico. Pesquisa Agropecuária Tropical 45(1):29-38. doi: 10.1590/1983$40632015 v 4528018$.

Raij, BV, Cantarella H, Quaggio JA, Furlani AMC (1997) Recomendações de adubação e calagem para o Estado de São Paulo. Campinas: Instituto Agronômico e Fundação IAC. 285p. (Boletim Técnico, 100).
Raij BV, Andrade JC, Cantarella H, Quaggio JA (2001) Análise química para avaliação da fertilidade de solos tropicais. IAC. 285p.

Rodella AA (1983) Métodos de análise de solo, tecido vegetal, vinhaça e torta de filtro. In: Orlando Filho, J. Nutrição e adubação da cana-de-açúcar no Brasil. PLANALSUCAR. p. 351-368.

Rubido MG, Espinosa RR, Hernandez YC, Aguiar YA, Cabrera JR (2017) Response of Canavalia ensiformis (L.) to inoculation with different arbuscular mycorrhizae fungi strains in a farl soil. Cultivos Tropicales 38(1):7-12.

Silva DRG, Marchi G, Spehar CR, Guilherme LRG, Rein TA, Soares DA, William FA (2012) Characterization and nutrient release from silicate rocks and influence on chemical changes in soil. Revista Brasileira de Ciência do Solo 36(3):951-962. doi: 10.1590/S010006832012000300025.

Silva FAZ, Azevedo CAV (2016) Comparison of means of agricultural experimentation data through different tests using the software Assistat. African Journal of Agricultural Research 11(37):3527-3531. doi: 10.5897/AJAR2016.11523.

Souza MDB, Fontanetti A, Lopes-Assad MLRC (2017) Efeito de remineralizador, vinhaça e plantas de cobertura nos atributos químicos do solo. Revista Ciência, Tecnologia e Ambiente 5(1):1-7.

Straaten PV (2006) Farming with rocks and minerals: challenges and opportunities. Anais da Academia Brasileira de Ciências 78(4):731-747. doi: 10.1590/S0001-37652006000400009.

Vieira NMB, Andrade MJB, Carvalho JG, Alves Junior J, Morais AR (2008) Altura de planta e acúmulo de matéria seca do feijoeiro cvs. BRS MG Talismã e Ouro Negro em plantio direto e convencional. Ciência e Agrotecnologia 32(6):1687-1693. doi: 10.1590/S141370542008000600001 .

Vieira NMB (2006) Crescimento e marcha de absorção de nutrientes no feijoeiro cvs. BRS-MG talismã e ouro negro, em plantio direto e convencional. UFLA (Dissertação de mestrado em Agronomia). 